\title{
Influence of housing system on the growth and histological structure of duck muscles
}

\author{
K. Damaziak ${ }^{1}$, M. Michalczuk ${ }^{1 \#}$, D. Adamek ${ }^{2}$, M. Czapliński ${ }^{1}$, J. Niemiec $^{1}$ \\ A. Goryl ${ }^{3}$ \& D. Pietrzak ${ }^{4}$ \\ ${ }^{1}$ Department of Animal Breeding and Production, University of Life Sciences, 02-786, Warsaw, Poland \\ ${ }^{2}$ Department of Ichthyobiology and Fisheries, University of Life Sciences, 02-786, Warsaw, Poland \\ ${ }^{3}$ Cracow University of Economics, 31-510, Cracow, Poland \\ ${ }^{4}$ Department of Food Technology, University of Life Sciences, 02-776, Warsaw, Poland
}

(Received 15 July 2013; Accepted 10 March 2014; First published online 10 April 2014)

\begin{abstract}
Copyright resides with the authors in terms of the Creative Commons Attribution 2.5 South African Licence.
See: http://creativecommons.org/licenses/by/2.5/za

Condition of use: The user may copy, distribute, transmit and adapt the work, but must recognise the authors and the South African Journal of Animal Science.
\end{abstract}

\begin{abstract}
This study was aimed at determining the effect of housing systems on the growth, feed conversion ratio (FCR), meatiness and size of muscle fibres of Pekin (P44) and Muscovy (MR71) ducks. Each genetic group included 360 birds (180 males and 180 females). The ducks were divided into four experimental groups according to their sex and housing system: intensive system (IS) and outdoor system (OS). A significant effect of housing system on the final body weight and FCR value was noted only in P44 birds of both sexes, with OS birds having higher body weights than the IS birds. As a result, the OS MR71 drakes were characterized by a significantly higher slaughter yield, weight and content of breast muscles in the carcass. The OS MR71 ducks showed a lower slaughter yield and a higher content of leg muscles in the carcass compared to IS MR71 ducks. In contrast, the housing system had no significant effect on the meatiness of P44 ducks. A greater diameter of muscle fibres in both sexes of P44 ducks and in both sexes of MR71 ducks was observed in the OS compared to IS flocks. A greater cross section of muscle fibres was also noted in the ducks from the OS system, however with significant differences confirmed only in pectoralis superficialis and biceps femoris in MR71 drakes as well as in the biceps femoris of P44 drakes. These data show differences between duck genotypes and indicate the efficiency and potential of outdoor poultry systems.
\end{abstract}

\footnotetext{
Keywords: Poultry production, outdoor system, intensive system, Pekin, Muscovy

\# Corresponding author: monika_michalczuk@sggw.pl

${ }^{5}$ Current address: Department of Animal Breeding and Production, University of Life Sciences, 02-786, Warsaw, Poland
}

\section{Introduction}

Ducks are reared in all regions of the world, whilst the size and trends of their production are strongly diversified as affected by tradition and culture of particular countries. The greatest world producer of ducks is China which contributes up to $73 \%$ of the global production. Together with other countries, south-eastern Asia contributes $83 \%$ of global production of this species (Cherry \& Morris, 2008). The concentration of duck production in the Asian countries results, most of all, from the tradition of consumption of their meat and eggs. Different breeds, lines and strains of Anatini ducks, including Pekin, Aylesbury or Rouen, are used for meat production in Asia, America and in most European countries. An exception is France where, as reported by Sauveur (1990), 85\% of production is based on Muscovy duck. Hence this breed is often called a "French duck" or "Barbarie duck". Contrary to the Asian countries known for the mass-scale, integrated, extensive production of rice as well as fish and ducks (Zhang et al., 2009), in Europe the production of poultry is based mainly on intensive systems. The intensification of rearing has enabled increasing production at lower financial inputs (Mench, 1992). A negative effect of this type of rearing is, however, poorer quality of products and deteriorated welfare of the birds. Ducks kept in the intensive system are characterized by, among other things, many behavioural disorders that often lead to self-mutilations and cannibalism (Raud \& Faure, 1994; Erisir et al., 2009). In response to a growing interest in higher-quality products originating from animals kept under conditions ensuring their welfare (Horne \& Achterbosch, 2008), a study was undertaken with the aim of comparing the growth, feed conversion ratio (FCR), meatiness and histological structure of muscles of Pekin and Muscovy ducks reared under two production systems. 


\section{Material \& Methods}

The experiment was conducted with Muscovy ducks (Grimaud, Rossy, France) of the R71 line (MR71) (Grimaud Fréres, 2012) and Polish Pekin ducks of the P44 line (P44) (Kokoszyński et al., 2010). Each genetic group included 360 birds (180 males and 180 females). The birds were divided according to their origin, sex and housing system. Neither declawing nor beak trimming was conducted in any of the groups. Up to three weeks of age all birds were kept according to the guidelines for intensive production system on deep litter and at a stocking density of $2.9 \mathrm{bird} / \mathrm{m}^{2}$. Thereafter, half the ducks and drakes of each genetic group was allowed to use free ranges, at a stock density of 0.08 bird $/ \mathrm{m}^{2}$ (outdoor system - OS). Free ranges were available to birds for the period of May to July, i.e. the period with the most intensive vegetation (Warsaw; $52.259^{\circ} \mathrm{N}, 21.020^{\circ} \mathrm{E}$ ). During the experiment, the average daily temperature and humidity were respectively, $18.4{ }^{\circ} \mathrm{C}$ and $84.6 \%$ in May, $21.1{ }^{\circ} \mathrm{C}$ and $79.6 \%$ in June and $22.0{ }^{\circ} \mathrm{C}$ and $81.3 \%$ in July, with nine days of rain and a total precipitation of $41.5 \mathrm{~mm}$. Ground predators were excluded by electric net fencing and overhead predators were excluded by netting over the paddocks. The remaining birds were kept under conditions of intensive production (IS) throughout the rearing period. In both production systems the birds were kept in sub-groups of 30 ducks. The P44 ducks and drakes were kept until 7 weeks of age, whereas the MR71 ducks until 10 weeks of age, and MR71 drakes until 12 weeks of age. Owing to differences in duration of rearing, the placement of ducklings was also conducted in different terms, which enabled synchronizing slaughter so that all birds were slaughtered on the same day. Throughout the rearing period, body weights of the birds were recorded individually $( \pm 1.0 \mathrm{~g})$ and feed intake $(\mathrm{kg} / \mathrm{bird})$ was recorded in groups $( \pm 0.1 \mathrm{~g})$ at weekly intervals. The ducks were fed ad libitum with standard feed concentrates for particular rearing periods (Table 1). The ducks kept outdoor had additionally the possibility of complementing their diets with fresh vegetation, the composition of which is presented in Table 2. The fresh vegetation was collected for analyses three times in 4-week intervals from five randomly-selected sites with the use of a $1 \mathrm{~m}^{2}$ frame. The mowing was done at the height of $3 \mathrm{~cm}$. The composition of basal diet and fresh vegetation was determined with the AOAC method (AOAC, 2005).

Table 1 Nutritive value of basal diet fed to Pekin (P44) and Muscovy (MR71) ducks according to their ages

\begin{tabular}{|c|c|c|c|c|c|c|}
\hline \multirow[b]{3}{*}{ Parameter } & \multirow{3}{*}{ Unit } & \multicolumn{2}{|c|}{ P44 } & \multicolumn{3}{|c|}{ MR71 } \\
\hline & & \multicolumn{5}{|c|}{ Age of ducks (weeks) } \\
\hline & & $0-2$ & $3-7$ & $0-3$ & $4-10$ & $\begin{array}{c}11-12 \\
\text { (males) }\end{array}$ \\
\hline$E M_{N}$ & kcal & 2925 & 3100 & 2850 & 3000 & 3100 \\
\hline$E M_{N}$ & MJ & 12.2 & 12.9 & 11.9 & 12.5 & 12.9 \\
\hline Crude protein & $\%$ & 20.0 & 18.0 & 20.5 & 19.0 & 17.5 \\
\hline Crude fibre & $\%$ & 4.0 & 5.0 & 4.0 & 5.0 & 6.0 \\
\hline Crude fat & $\%$ & 5.0 & 7.0 & 5.0 & 6.0 & 7.0 \\
\hline \multicolumn{7}{|l|}{ Amino acids } \\
\hline Lysine & $\%$ & 1.1 & 1.0 & 1.0 & 0.9 & 0.8 \\
\hline Methionine & $\%$ & 0.5 & 0.4 & 0.5 & 0.4 & 0.4 \\
\hline \multicolumn{7}{|l|}{ Minerals } \\
\hline Calcium (Ca) & $\%$ & 1.1 & 0.9 & 1.1 & 0.9 & 0.8 \\
\hline Phosphorus (P) & $\%$ & 0.5 & 0.4 & 0.5 & 0.4 & 0.4 \\
\hline Sodium (Na) & $\%$ & 0.2 & 0.2 & 0.2 & 0.2 & 0.2 \\
\hline \multicolumn{7}{|l|}{ Vitamins } \\
\hline A & IU & 13500 & 12000 & 15000 & 10000 & 10000 \\
\hline $\mathrm{D}_{3}$ & IU & 3000 & 2000 & 3000 & 2000 & 2000 \\
\hline $\mathrm{E}$ & $\mathrm{mg}$ & 20 & 20 & 20 & 20 & 15 \\
\hline
\end{tabular}

$E M_{N}$ - is the gross energy of the feed consumed minus the gross energy contained in the faeces, urine, and gaseous products of digestion. For poultry EM represents the gross energy of the feed minus the gross energy of the excreta. A correction for nitrogen retained in the body is usually applied to yield a nitrogen-corrected EM (EMN) value. 

2009).

Experimental procedures were approved by the Ethical Commission (approval no. 27/2009 of 16 April

At the end of rearing, after 12-h fasting, 12 males and 12 females with body weights similar to the mean body weights for a particular sex in a group, were selected from each group. The birds were slaughtered using an electrical waterbath stunner supplied with 380 volts, $50 \mathrm{~Hz}$ sine wave alternating current for $4 \mathrm{~s}$, as practised normally in a processing plant. Thereafter, the birds were bled for ca. 3 min and scalded in water at a temperature of $68^{\circ} \mathrm{C}$ for $2 \mathrm{~min}$. After manual plucking and evisceration, carcasses were placed in a cold store at a temperature of $4{ }^{\circ} \mathrm{C}$. After $24 \mathrm{~h}$ of chilling, the carcasses were weighed $( \pm 1.0 \mathrm{~g})$, and then breast and leg muscles were separated according to the method of goose dissection described by Bochno et al. (2006).

Table 2 Results of chemical analysis ( $\mathrm{g} / \mathrm{kg} \mathrm{DM}$ ) of fresh vegetation growing on free ranges for ducks

\begin{tabular}{lccccc}
\hline Month & $\begin{array}{c}\text { Dry } \\
\text { matter }\end{array}$ & $\begin{array}{c}\text { Organic } \\
\text { matter }\end{array}$ & $\begin{array}{c}\text { Crude } \\
\text { protein }\end{array}$ & $\begin{array}{c}\text { Crude } \\
\text { fibre }\end{array}$ & $\begin{array}{c}\text { N-free } \\
\text { extract }\end{array}$ \\
\hline \multirow{3}{*}{ May } & 288.1 & 933.6 & 110.3 & 326.4 & 452.8 \\
June & 290.6 & 941.2 & 60.5 & 353.0 & 441.6 \\
July & 311.0 & 938.7 & 69.7 & 367.3 & 490.2 \\
\hline
\end{tabular}

Samples of pectoralis superficialis and biceps femoris muscles were collected for histological analyses from the right side (near the keel) immediately after slaughter from 6 drakes and 6 ducks of both lines (P44 and MRF1, one sample per bird). Cuts were made perpendicular to the course of muscle fibres to obtain blocks of $1 \times 1 \times 1 \mathrm{~cm}^{3}$. The samples were fixed in Bouin's fluid $(24 \mathrm{~h})$ and embedded in paraffin blocks. The resultant preparations were cut crosswise into $5 \mu \mathrm{m}$ sections using a semi-automatic microtome (Leica RM 2265), and then dried at a temperature of $37^{\circ} \mathrm{C}$ for $24 \mathrm{~h}$. Histological preparations were stained with the standard H\&E method (Ostaszewska et al., 2008). Images of the preparations were achieved using a Nikon optical microscope (type 104c). This work presents differences in the thickness and density of duck muscle fibres depending on the housing system. The following measurements were carried out for each analysed muscle of 300 muscle fibres selected at random, using the following mathematical relationship (Teuşan et al., 2011):

$$
\overline{D \times}=\frac{D l+D s}{2}
$$

where: $D \bar{x}$ mean diameter $(\mu \mathrm{m}) ; D I$ - large diameter of myocytes $(\mu \mathrm{m}) ; D s$ - small diameter of myocytes $(\mu \mathrm{m})$;

where: If - format index of muscle fibres (\%);

$$
\text { If }=\frac{D s \times 100}{D l}
$$

$$
\text { S.s.t. }=\frac{D l \times D s}{4} \times \pi
$$

where: S.s.t. - cross section area of muscle myocytes $\left(\mu \mathrm{m}^{2}\right) ; \pi$ - circle area ratio with official value of 3.141592654;

$$
\text { D.f.m. }=\frac{n \times 10^{6}}{\text { Sst }}
$$

where: D.f.m. - density of muscle fibres (f.m./mm²); $n$ - number of muscle fibres; Sst - muscle cross section area of the primary diameter $\left(\mu \mathrm{m}^{2}\right)$.

The data were used to determine ducks' growth over the entire rearing period, their FCR $(\mathrm{kg} / \mathrm{kg})$ and dressing percentage, and to characterize the histological structure of their pectoralis superficialis and biceps femoris. All computations were conducted with SPSS 19.0 statistical software (SPSS, 2010). Normality of traits distribution was verified with the Kołmogorow-Smirnow test. The effect of the analysed factors was estimated using GLM procedure. The growth was characterized using a Gompertz Model, being a reliable tool to describe a dependency between body weight and age of birds (Mignon-Greasteau \& Beaumont, 2000):

$$
Y=A^{\star} \operatorname{EXP}\left(-\operatorname{EXP}\left(-B^{*}(X-C)\right)\right)
$$


where: $Y$ - body weight of ducks; $X$ - age of ducks; $A$ - maximum body weight to be reached by ducks; $B$ rate of body weight gain and $C$ - abscissa of inflexion point, which means the moment of transition from the phase of accelerated growth into the phase of inhibited growth.

Due to various rearing periods of ducks, the significance of differences in their body weights was estimated using three-way analysis only from week 3 to week 7 (from week 3 , because until the $3^{\text {rd }}$ week all birds were kept under identical conditions; to week 7 , because after the $7^{\text {th }}$ week, analyses were continued only for MR71 ducks) according to the following model:

$$
Y_{i j m k}=\mu+P_{i}+U_{j}+R_{m}+(P U) i j+(P R) i m+(U R) j m+(P U R) i j m+e_{i j m k}
$$

where: $Y$ - trait; $\mu$-general mean; $P_{i}-$ effect of $\mathrm{i}$-th sex, $\mathrm{i}=1.2 ; U_{j}$ - effect of $\mathrm{j}$-th housing system; $R_{m}-$ effect of $\mathrm{m}$-th genotype; $\mathrm{m}=1.2 ;(P U) i j$ - effect of interaction between sex and housing system; $(P R) i m-$ effect of interaction between sex and genotype; (UR)jm - effect of interaction between housing system and genotype; (PUR)ijm - effect of interaction between sex, housing system and genotype; and $e_{i j k}$ - random error.

Between weeks 0 and 3, owing to a lack of differences in the housing system until the 3rd week of the birds' life, their body weights were analysed considering sex and genotype according to the model:

$$
Y_{i j k}=\mu+P_{i}+R_{m}+(P R)_{i m}+e_{i j k}
$$

where: $Y$ - trait; $\mu$-general mean; $P_{i}-$ effect of $\mathrm{i}$-th sex; $\mathrm{i}=1.2 ; R_{m}-$ effect of $\mathrm{m}$-th genotype, $\mathrm{m}=1.2$; $(P U)_{i j}$ - effect of interaction between sex and genotype; $e_{i j k}-$ random error.

Between weeks 8 and 10, the significance of differences in body weight of MR71 ducks and in FCR, dressing percentage, weight and content of muscles in body weight, and traits of muscle fibres of P44 ducks were investigated with the two-way analysis according to the following model:

$$
Y_{i j k}=\mu+P_{i}+U_{j}+(P U)_{i j}+e_{i j k}
$$

where: $Y$ - trait; $\mu$-general mean; $P_{i}$ - effect of $\mathrm{i}$-th sex; $\mathrm{i}=1.2 ; U_{j}$ - effect of $\mathrm{j}$-th housing system; $(P U)_{i j}$ - effect of interaction between sex and housing system; and $e_{i j k}$ - random error.

Between weeks 10 and 12 of birds' life, the body weights of MR71 drakes and additionally - in order to demonstrate the impact of housing system on body weight gains in all groups and on all other traits (FCR, dressing percentage, weight and content of muscles in body weight, traits of muscle fibres). The body weights of MR71 ducks owing to different rearing periods of males and females and to significantly longer rearing period in both sexes compared to P44 ducks, were analyzed using one factor (housing system) according to the following model:

$$
Y_{i j k}=\mu+S_{i}+e_{i j k}
$$

where: $Y_{i j k}$ trait; $\mu$-general mean; $S_{i}-$ effect of $i$-th housing system; and $e_{i j k}-$ random error.

The differences were considered significant at Pitalic $<0.01$ and $P<0.05$. The variability of the investigated traits was expressed by the standard error of the mean $( \pm \mathrm{SE})$.

All data obtained from measurements and calculations of muscle histology were processed and interpreted using statistical estimators: mean $(\bar{x})$ and standard deviation (s). To test the statistical significance of differences between the size of muscle fibres of ducks kept in the intensive and outdoor system, single factor ANOVA algorithm was applied, using Microsoft Excel software.

\section{Results \& Discussion}

In the current experiment, MR71 ducks reached body weights (Figure 1), which were higher than values reported earlier by other authors (Baéza et al., 1998; Wawro et al., 2004). Different housing conditions had a significant effect on the course of MR71 drakes' growth, in the case of which higher body weights were noted for the IS birds in weeks $7,8,9(P<0.05)$ and $10(P<0.01)$ of rearing. The analysis of the Gompertz model demonstrated that the maximum weekly body weight gain of MR71 IS drakes (690 g) occurred in week 5, whereas in the MR71 OS flock - in week 6 of the birds' life (609 g). Despite the more intensive growth of the MR71 IS drakes, at week 12 of life their body weights were lower by $199.1 \mathrm{~g}$, which were, however, not confirmed statistically (Figure 1). In the case of MR71 ducks, analyses did not confirm the effect of the housing system on their growth over the entire rearing period (Figure 1). A negligibly higher weekly maximum body weight gain was reported for ducks of the IS group ( $450 \mathrm{~g}$ ) between weeks 4 and 5 of life. In the MR71 OS flock, the most intensive body weight gains $(443 \mathrm{~g})$ were observed in week 4 of rearing. In contrast to MR71 drakes, a higher body weight at the end of rearing was recorded in MR71 IS ducks. However, the difference reached only $56.4 \mathrm{~g}$ and was not confirmed statistically.

Results of our study demonstrated also that the housing system had a greater impact on the growth of P44 ducks than on the growth of MR71 birds (Figure 1), which may result from higher susceptibility of this group of birds to environmental stress (Faure et al., 2003). Contrary to Muscovy ducks, the Pekin ducks are characterized by very dynamic growth, but only until 7 weeks of age, which in practice leads to earlier termination of their rearing (Wilkiewicz-Wawro et al., 1999). According to Gille \& Salomon (1998), this is due 


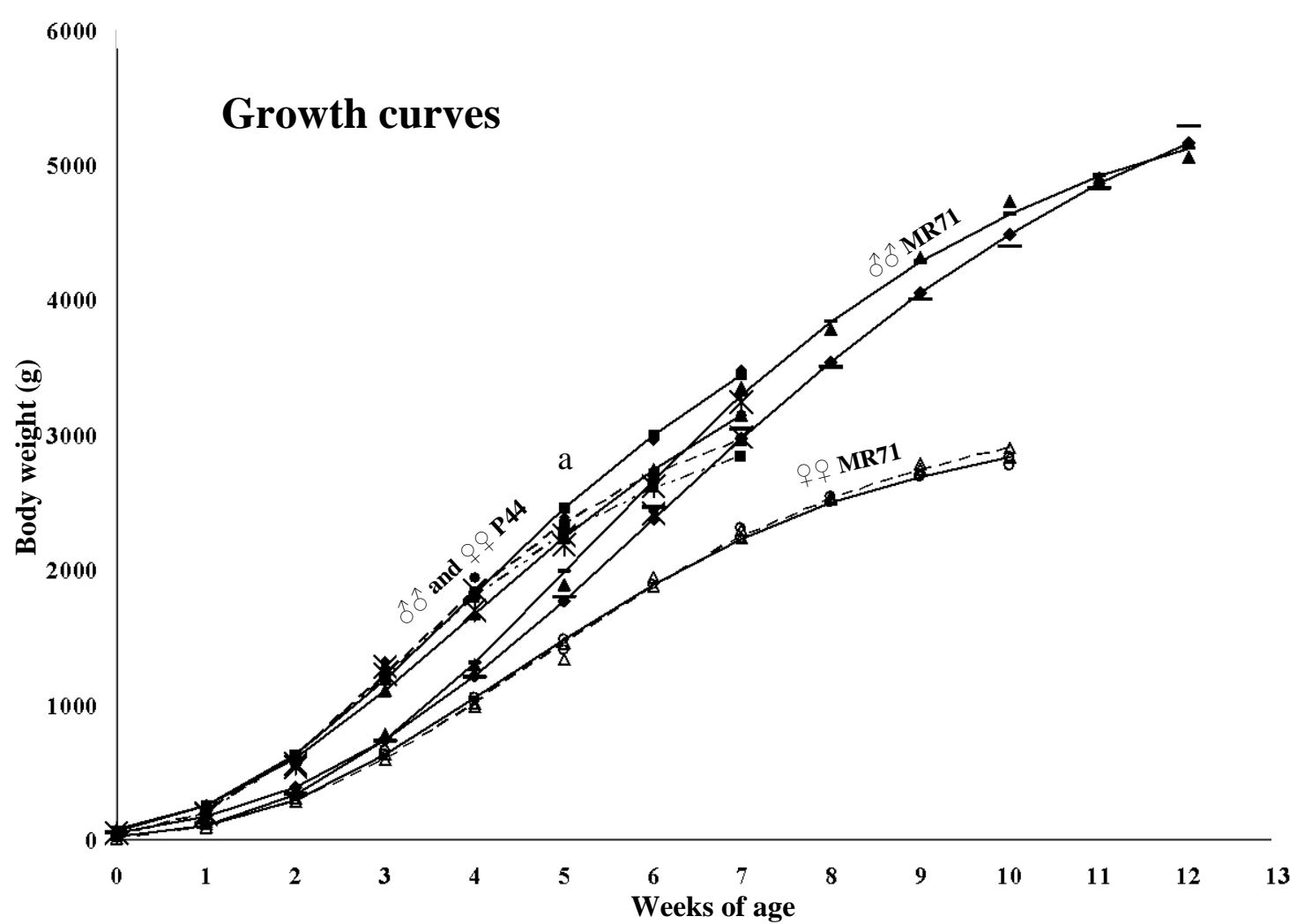

Figure 1 Growth curves of MR71 and Pekin P44 ducks kept intensively (IS) and kept outdoor (OS) as predicted by Gompertz model.

a interaction (genotype $\mathrm{x}$ sex $\mathrm{x}$ production system) differences significant at $P \leq 0.05$;

\begin{tabular}{|c|c|c|}
\hline Graphics & Description & Maintenance system \\
\hline & कें̂े P44 & OS \\
\hline$\rightarrow$ & के P44 & os \\
\hline - & ôे P44 & IS \\
\hline$-\rightarrow-$ & ô P44 & IS \\
\hline * & 우우 P44 & OS \\
\hline 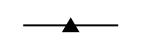 & 우우 P44 & os \\
\hline$x$ & 우우 P44 & IS \\
\hline$-\cdot-$ & 우 P44 & IS \\
\hline - & $\sigma^{\lambda} \mathrm{MR} 71$ & OS \\
\hline 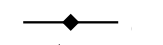 & के MR71 & OS \\
\hline $\boldsymbol{\Delta}$ & ổ MR71 & IS \\
\hline & के वै MR71 & IS \\
\hline$\circ$ & 우 MR71 & OS \\
\hline 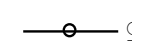 & 우우 MR71 & OS \\
\hline$\Delta$ & 우우 MR71 & IS \\
\hline$--\Delta--$ & 우우 MR71 & IS \\
\hline
\end{tabular}

OS - outdoor system; IS - intensive system.

to the different origins of the ducks. The maximum body weight gain in both sexes of P44 IS ducks was observed in week 3 (631 g-drakes; $615 \mathrm{~g}$ - ducks), whereas in P44 OS ducks - in week 4 of life (643 g drakes; $577 \mathrm{~g}$ - ducks). It may be observed, therefore, that allowing the ducks to use free ranges when they completed three weeks of age resulted in growth deceleration. As a consequence, the first significant differences were noted in the $4^{\text {th }}$ week in both drakes $(P<0.05)$ and ducks $(P<0.01)$. The higher body weight was reported in ducks from the IS group (Figure 1). In the later period of rearing, these dependencies were reversed and in week 6 the P44 OS drakes showed a higher $(P<0.01)$ body weight compared with the P44 
IS drakes. At the end of rearing, this difference has even increased and reached $343.3 \mathrm{~g}$, which was also confirmed significant at $P<0.01$. The P44 ducks from both housing systems maintained their body weights at a similar level for a longer period of time than the P44 drakes, but in week 7 of rearing the body weight of P44 OS ducks was already higher $(P<0.05)$ by $261.4 \mathrm{~g}$. Erisir et al. (2009) also achieved higher body weights in Pekin ducks kept outdoors. According to these authors, such a system of rearing improves microclimatic conditions for birds, especially in the case of waterfowls.

The statistical analysis including simultaneously three factors (genotype $\mathrm{x}$ sex $\mathrm{x}$ housing system) demonstrated a significant $(P<0.05)$ interaction only in the $5^{\text {th }}$ week of the ducks' life (Figure 1$)$. Higher body weights were then recorded for P44 ducks compared to MR71 birds, as well as for IS birds compared to OS birds. Males had higher body weights than females. This was presumably linked with body weight decrease as a result of OS birds' adaptation to new housing conditions. The higher body weight of P44 ducks in the $5^{\text {th }}$ week is due to a higher growth rate of this genetic group (Wilkiewicz-Wawro et al., 1999). The P44 ducks, compared to MR71 birds, are able to adapt faster to variable environmental conditions, which could be indicated by lesser body weight decreases after allowing the birds to use free ranges.

In both MR71 drakes and ducks, the housing system was found not to affect FCR. Insignificantly higher FCR values were noted in MR71 IS drakes $(2.55 \pm 0.03)$ in comparison to the OS group $(2.45 \pm 0.05)$ as well as in MR71 IS ducks (2.14 \pm 0.02$)$ compared to MR71 OS ducks $(2.11 \pm 0.05)$. In both sexes of P44 birds, significant differences were observed in FCR values. The highest FCR value was noted in P44 IS drakes $(2.45 \pm 0.02)$, and it was higher $(P<0.01)$ than in the P44 OS drakes $(2.05 \pm 0.01)$. The difference between ducks was also significant, but at $P<0.05$. The FCR of P44 IS ducks accounted for $2.28( \pm 0.01)$ and that of P44 OS ducks for $1.93( \pm 0.01)$. These results confirm earlier findings which indicate that providing the birds with more space for free movement decreases feed intake and improves FCR (Michael \& Huonnic, 2003; Erisir et al., 2009). Although it is difficult to determine the intake of fresh vegetation in birds kept outdoors, it may be speculated that the lower FCR value in the OS group could have been due also to a higher intake of green forage.

Tables 3 and 4 present results of slaughter yield and content (\%) of breast and leg muscles in carcasses of MR71 and P44 ducks. The impact of the housing system on slaughter yield was confirmed only in both sexes of MR71 birds. However, in the case of drakes its value was significantly $(P<0.05)$ higher in the OS flock, and in the case of ducks - in the IS flock (Table 3). Etuk et al. (2006) obtained opposite results, as in their study both male and female Muscovy ducks kept on pasture showed a lower slaughter yield compared to birds kept in an intensive system.

Results obtained in our study showed a significant $(P<0.01)$ effect of the housing system on the weight and percentage content of breast muscles in carcass weight in the case of MR71 drakes and on the percentage content of leg muscles in MR71 ducks $(P<0.05)$ (Table 3). In the case of P44 ducks, the housing systems had no effect on any of the analysed traits (Table 4). It may be speculated that the greater impact of the housing system on muscle development in MR71 ducks, compared to P44 ducks, results from a considerably longer period of rearing and consequently from a longer period of using free ranges. The Muscovy ducks are additionally characterized by slower development of breast muscles which in the case of drakes occurs in 10 - 12 weeks of life (Sauveur, 1990; Gille \& Salomon, 1998). Until then, the MR71 OS

Table 3 Least square means (LSM) and \pm SE of slaughter yield (\%) as well as weight ( $g$ ) and content in the carcass (\%) of breast and leg muscles of both sexes MR71 ducks kept intensively (IS) and in the outdoor system (OS)

\begin{tabular}{|c|c|c|c|c|c|}
\hline \multirow{2}{*}{ Parameter } & & \multicolumn{2}{|c|}{$\begin{array}{c}\text { Male } \\
(n=12)\end{array}$} & \multicolumn{2}{|c|}{$\begin{array}{l}\text { Female } \\
(n=12)\end{array}$} \\
\hline & & IS & os & IS & os \\
\hline Carcass & (\%) & $68.0^{\mathrm{b}} \pm 0.6$ & $70.6^{a} \pm 0.6$ & $68.9^{a} \pm 0.4$ & $67.7^{b} \pm 0.4$ \\
\hline \multirow{2}{*}{ Breast muscle } & g & $673.3^{B} \pm 23.2$ & $781.8^{A} \pm 21.2$ & $369.5 \pm 29.4$ & $355.1 \pm 29.4$ \\
\hline & ratio $^{1}$ & $20.5^{B} \pm 0.5$ & $22.8^{\mathrm{A}} \pm 0.4$ & $19.7 \pm 1.6$ & $20.1 \pm 1.6$ \\
\hline \multirow{2}{*}{ Leg muscle } & $\mathrm{g}$ & $455.5 \pm 21.4$ & $472.9 \pm 19.5$ & $245.9 \pm 6.1$ & $246.5 \pm 6.1$ \\
\hline & ratio $^{1}$ & $13.8 \pm 0.5$ & $13.8 \pm 0.5$ & $13.2^{\mathrm{b}} \pm 0.2$ & $13.9^{\mathrm{a}} \pm 0.2$ \\
\hline
\end{tabular}

\footnotetext{
${ }^{\mathrm{A}, \mathrm{B}}$ - difference significant at $P \leq 0.01 ;{ }^{\mathrm{a}, \mathrm{b}}$ - difference significant at $P \leq 0.05$.

${ }^{1}$ ratio - the ratio (\%) of breast muscle and leg muscles weight to carcass weight.

Tested the significant of difference within only one sex.
} 
drakes that were using free ranges for ca. 7 weeks had, presumably, enough time to adapt to new environmental conditions and to be more effective in utilizing the pasture than the P44 ducks.

In the reported experiment, the possibility of using free ranges contributed to an increase in muscle fibre diameters in both analysed muscles, both in MR71 (Table 5) and P44 ducks (Table 7). The exception was the pectoralis superficialis muscles of MR71 females, where the fibre diameter was greater in the OS group (by $1.9 \mu \mathrm{m}$ ), but statistical significance was not confirmed. Correlations $(r)$ between fibre diameters and muscle weight were always positive but not high (Tables 6 and 8). Higher positive correlations were reported between muscle weight and cross-section area of muscle fibres, which ranged from 0.37 to 0.46 in MR71 ducks and from 0.33 to 0.41 in P44 ducks. Noteworthy is the fact that the differences in the diameter and cross-sectional area of muscle fibres were greater in biceps femoris muscle mainly in drakes (Figures 2 5), where they were confirmed significant (MR71 at $P<0.01$; P44 at $P<0.05$ ). According to Lin \& Hsu (2002), it may be due to a high concentration of testosterone in blood which stimulates muscle fibres to grow. Gille \& Salomon (1998) report additionally that, contrary to gallinaceous poultry, ducks are characterized by more intensive growth of limbs after hatching, and that keeping ducks outdoor predisposes them to increased physical activity. The greater differences in the area of muscle fibres of biceps femoris may, thus, result from the fact that in young ducks this group of muscles performs significantly more intensive work during walking, running and body weight support than the pectoralis superficialis muscle (Figures 2 and 3).

Table 4 Least square means (LSM) and \pm SE of slaughter yield (\%) as well as weight (g) and content in the carcass (\%) of breast muscles and leg muscles of female and male P44 ducks kept intensively (IS) and in the outdoor system (OS)

\begin{tabular}{lcccccc}
\hline Parameter & & \multicolumn{2}{c}{$\begin{array}{c}\text { Male } \\
(\mathbf{n = 1 2})\end{array}$} & \multicolumn{2}{c}{$\begin{array}{c}\text { Female } \\
(\mathbf{n}=\mathbf{1 2})\end{array}$} & $\begin{array}{c}\text { P-value } \\
\text { S } \boldsymbol{x} \text { Ps }\end{array}$ \\
\cline { 2 - 6 } & & IS & OS & IS & OS & \\
\hline Carcass & $(\%)$ & $68.6 \pm 0.6$ & $67.9 \pm 0.6$ & $70.0 \pm 0.6$ & $68.2 \pm 0.6$ & 0.55 \\
Breast muscle & $\mathrm{g}$ & $262.8 \pm 11.3$ & $275.2 \pm 11.3$ & $268.2 \pm 15.7$ & $249.4 \pm 15.7$ & 0.26 \\
& ratio $^{1}$ & $12.5 \pm 0.4$ & $12.1 \pm 0.4$ & $13.3 \pm 0.8$ & $12.1 \pm 0.8$ & 0.59 \\
Leg muscle & $\mathrm{g}$ & $253.4 \pm 5.7$ & $256.7 \pm 5.7$ & $224.0 \pm 9.6$ & $239.9 \pm 9.6$ & 0.43 \\
& ratio $^{1}$ & $12.1 \pm 0.4$ & $11.3 \pm 0.4$ & $11.1 \pm 0.4$ & $11.6 \pm 0.4$ & 0.10
\end{tabular}

There was no significant effect of the housing system and no significant interaction (were: S - sex; Ps - production system) on the presented parameters.

${ }^{1}$ ratio - the ratio (\%) of breast muscle and leg muscles weight to carcass weight.

Contrary to the gallinaceous poultry in which muscles are built almost exclusively from large white fibres ( $\alpha \mathrm{W})$, muscles of ducks consist mainly of red fibres $(\beta R)$ with smaller diameters (Swatland, 1980; Witkiewicz et al., 2004). In our experiment, the contribution of small fibres fitted within the range of $73.5 \%$ $77.1 \%$ (males) and $78.1 \%-79.7 \%$ (females) in pectoralis superficialis muscles of MR71 ducks, and within the range of $76.7 \%-76.6 \%$ (males) and $71.5 \%-76.4 \%$ (females) in P44 ducks. In biceps femoris muscles the contribution of small fibres was $81.5 \%-83.7 \%$ (males) and $91.0 \%-90.0 \%$ (females) in MR71 ducks, and $86.3 \%-86.3 \%$ (males) and $76.6 \%-76.7 \%$ (females) in P44 ducks. There were no statistically significant differences in percentages of particular fibres associated with the housing system of the ducks (Tables 5 and 7). According to Kisiel \& Książkiewicz (2004) and Witkiewicz et al. (2004), it is a genetic trait that is typical of the waterfowls. In turn, the statistical analysis confirmed the significant $(P<0.05)$ effect of the housing system on diameter of both large and small muscle fibres in the case of pectoralis superficialis and biceps femoris of MR71 drakes, which was higher in birds from the OS group (Table 5). This is, probably, linked with the longest rearing period and with the most intensive growth of mainly pectoral muscles in this group of ducks, which may be indicated also by results of dissection (Tables 3 and 4). The diameters of small muscle fibres in P44 ducks did not differ according to housing system (IS, OS) in both sexes (Table 7). The P44 drakes were characterized by greater diameters of large fibres of biceps femoris muscle (Table 7).

Determination of diameter $(\mu \mathrm{m})$ and cross-section area $\left(\mu \mathrm{m}^{2}\right)$ of muscle fibres enabled calculating their index. Muscle fibres of MR71 IS females were always thinner, and in the case of males these differences were confirmed significant $(P<0.01)$ in both pectoralis superficialis and biceps femoris muscles 
Table 5 Means $(\bar{X})$ and standard deviation (s) of the thickness and density of the myocytes of pectoralis superficialis and biceps femoris muscle fibres in female and male MR71 ducks kept intensively (IS) and in the outdoor system (OS)

\begin{tabular}{|c|c|c|c|c|c|c|c|}
\hline \multirow{2}{*}{ Parameter } & & & & \multicolumn{2}{|c|}{ Pectoralis superficialis muscle } & \multicolumn{2}{|c|}{ Biceps femoris muscle } \\
\hline & & & & IS & os & IS & OS \\
\hline \multirow{4}{*}{$\begin{array}{l}\text { Diameter of } \\
\text { large fibres } D I\end{array}$} & \multirow{4}{*}{$\mu \mathrm{m}$} & \multirow{2}{*}{$\mathrm{M}$} & $\bar{x}$ & $50.3^{\mathrm{b}} \pm 4.7$ & $52.8^{\mathrm{a}} \pm 6.4$ & $63.4 \pm 8.8$ & $63.6 \pm 8.2$ \\
\hline & & & ratio $^{1}$ & $22.9 \pm 3.4$ & $26.5 \pm 3.7$ & $16.3 \pm 4.6$ & $18.5 \pm 5.1$ \\
\hline & & \multirow{2}{*}{$\mathrm{F}$} & $\bar{x}$ & $40.3 \pm 3.7$ & $39.4 \pm 3.4$ & $42.6 \pm 4.2$ & $44.3 \pm 4.4$ \\
\hline & & & ratio $^{1}$ & $20.3 \pm 3.2$ & $21.9 \pm 3.5$ & $16.0 \pm 5.0$ & $9.0 \pm 3.3$ \\
\hline \multirow{4}{*}{$\begin{array}{l}\text { Diameter of } \\
\text { small fibres } \\
\text { Ds }\end{array}$} & \multirow{4}{*}{$\mu \mathrm{m}$} & \multirow{2}{*}{ M } & $\bar{X}$ & $23.2^{\mathrm{b}} \pm 4.1$ & $25.6^{\mathrm{a}} \pm 4.4$ & $33.7 \pm 7.6$ & $35.3 \pm 6.9$ \\
\hline & & & ratio $^{1}$ & $77.1 \pm 11.4$ & $73.5 \pm 10.6$ & $83.7 \pm 13.7$ & $81.5 \pm 12.9$ \\
\hline & & \multirow{2}{*}{$\mathrm{F}$} & $\bar{X}$ & $18.9 \pm 2.8$ & $19.5 \pm 3.4$ & $20.7 \pm 2.6$ & $21.8 \pm 1.3$ \\
\hline & & & ratio $^{1}$ & $79.7 \pm 11.8$ & $78.1 \pm 11.2$ & $84.0 \pm 12.4$ & $91.0 \pm 13.0$ \\
\hline \multirow{4}{*}{$\begin{array}{l}\text { Mean } \\
\text { diameter of } \\
\text { fibres } D \bar{X} \\
\text { Surface in } \\
\text { cross section } \\
\text { of fibres S.s.t. }\end{array}$} & \multirow[b]{2}{*}{$\mu \mathrm{m}$} & M & & $39.6^{\mathrm{b}} \pm 0.8$ & $42.6^{a} \pm 0.8$ & $50.0^{B} \pm 1.3$ & $54.0^{\mathrm{A}} \pm 1.2$ \\
\hline & & $\mathrm{F}$ & & $34.5 \pm 0.7$ & $36.4 \pm 0.7$ & $35.2^{b} \pm 0.8$ & $37.8^{\mathrm{a}} \pm 0.9$ \\
\hline & \multirow{2}{*}{$\mu \mathrm{m}^{2}$} & M & & $1185^{B} \pm 344.6$ & $1333^{A} \pm 353.8$ & $1213^{B} \pm 356.4$ & $1429^{A} \pm 358.0$ \\
\hline & & $\mathrm{F}$ & & $878.9 \pm 237.3$ & $900.6 \pm 238.3$ & $985.0 \pm 264.2$ & $1095.3 \pm 270.3$ \\
\hline \multirow{2}{*}{$\begin{array}{l}\text { Fibres density } \\
\text { D.f.m. }\end{array}$} & \multirow{2}{*}{$\mathrm{fm} / \mathrm{mm}^{2}$} & $M$ & & $627.9^{a} \pm 122.3$ & $508.6^{\mathrm{b}} \pm 81.0$ & $443.9^{a} \pm 56.0$ & $312.3^{b} \pm 52.2$ \\
\hline & & $\mathrm{F}$ & & $698.2 \pm 166.6$ & $654.1 \pm 127.0$ & $602.5^{\mathrm{a}} \pm 98.0$ & $557.7^{b} \pm 65.9$ \\
\hline \multirow{2}{*}{$\begin{array}{l}\text { Fibres index } \\
\text { format If }\end{array}$} & \multirow{2}{*}{$\%$} & $M$ & & $66.4^{B} \pm 12.2$ & $69.6^{\mathrm{A}} \pm 13.4$ & $69.5^{b} \pm 16.1$ & $71.0^{\mathrm{a}} \pm 17.5$ \\
\hline & & $\mathrm{F}$ & & $73.0 \pm 10.5$ & $74.0 \pm 12.8$ & $71.7 \pm 11.3$ & $72.3 \pm 10.0$ \\
\hline
\end{tabular}

Table 6 Correlation coefficients $(r)$ between breast and leg muscle weight and pectoralis superficialis and biceps femoris muscle fibre size in female and male MR71 ducks kept intensively (IS) and in the outdoor system (OS)

\begin{tabular}{|c|c|c|c|c|c|c|c|c|}
\hline \multirow[t]{2}{*}{ Parameter } & & & \multicolumn{2}{|c|}{$\begin{array}{l}\text { Mean diameter of } \\
\quad \text { fibres } D \bar{X}\end{array}$} & \multicolumn{2}{|c|}{$\begin{array}{c}\text { Cross section of } \\
\text { fibres S.s.t. }\end{array}$} & \multicolumn{2}{|c|}{$\begin{array}{c}\text { Fibres density } / \mathrm{mm}^{2} \\
\text { D.f.m. }\end{array}$} \\
\hline & & & IS & os & IS & os & IS & os \\
\hline \multirow{6}{*}{$\begin{array}{l}\text { Pectoralis } \\
\text { superficialis }\end{array}$} & \multirow{2}{*}{ Weight $^{1}(\mathrm{~g})$} & M & 0.16 & 0.17 & 0.37 & 0.44 & -0.02 & -0.17 \\
\hline & & $\mathrm{F}$ & 0.18 & 0.20 & 0.42 & 0.46 & -0.13 & -0.13 \\
\hline & \multirow{2}{*}{$\begin{array}{l}\text { Mean diameter } \\
\text { of fibres } D \bar{X}\end{array}$} & $M$ & & & 0.65 & 0.68 & -0.65 & -0.74 \\
\hline & & $\mathrm{F}$ & & & 0.67 & 0.65 & -0.57 & -0.71 \\
\hline & \multirow{2}{*}{$\begin{array}{l}\text { Cross section of } \\
\text { fibres S.s.t. }\end{array}$} & M & & & & & -0.32 & -0.39 \\
\hline & & $\mathrm{F}$ & & & & & -0.33 & -0.40 \\
\hline \multirow{6}{*}{$\begin{array}{l}\text { Biceps } \\
\text { femoris }\end{array}$} & \multirow{2}{*}{ Weight (g) } & M & 0.18 & 0.23 & 0.39 & 0.47 & -0.12 & -0.10 \\
\hline & & $\mathrm{F}$ & 0.16 & 0.21 & 0.26 & 0.34 & -0.07 & -0.06 \\
\hline & \multirow{2}{*}{$\begin{array}{l}\text { Mean diameter } \\
\text { of fibres } D \bar{X}\end{array}$} & $M$ & & & 0.58 & 0.63 & -0.84 & -0.98 \\
\hline & & $\mathrm{F}$ & & & 0.51 & 0.57 & -0.83 & -0.88 \\
\hline & \multirow{2}{*}{$\begin{array}{l}\text { Cross section of } \\
\text { fibres S.s.t. }\end{array}$} & $M$ & & & & & -0.34 & -0.39 \\
\hline & & $\mathrm{F}$ & & & & & -0.27 & -0.29 \\
\hline
\end{tabular}

\footnotetext{
${ }^{1}$ whole breast muscle; $\mathrm{M}$ - Males; F - Females.
} 
Table 7 Means $(\bar{x})$, standard deviation (s) and $\mathrm{P}$ - value for interaction (sex $\mathrm{x}$ production system) of the thickness and density of the myocytes of pectoralis superficialis and biceps femoris muscle fibres in female and male P44 ducks kept intensively (IS) and in the outdoor system (OS)

\begin{tabular}{|c|c|c|c|c|c|c|c|c|c|}
\hline \multirow[t]{2}{*}{ Parameter } & & & & \multicolumn{2}{|c|}{ Pectoralis superficialis } & \multirow{2}{*}{$\begin{array}{c}P \text {-value } \\
S \times P s\end{array}$} & \multicolumn{2}{|c|}{ Biceps femoris } & \multirow{2}{*}{$\begin{array}{l}P \text {-value } \\
S \times P s\end{array}$} \\
\hline & & & & IS & OS & & IS & OS & \\
\hline \multirow{4}{*}{ Diameter of large fibres $D I$} & \multirow{4}{*}{$\mu \mathrm{m}$} & \multirow{2}{*}{ M } & $\bar{x}$ & $37.9 \pm 3.2$ & $37.6 \pm 3.9$ & 0.617 & $54.2^{\mathrm{b}} \pm 6.9$ & $58.9^{\mathrm{a}} \pm 7.5$ & 0.143 \\
\hline & & & ratio $^{1}$ & $23.3 \pm 2.3$ & $23.4 \pm 2.8$ & 0.348 & $16.3 \pm 4.7$ & $18.5 \pm 5.7$ & 0.085 \\
\hline & & \multirow{2}{*}{$\mathrm{F}$} & $\bar{x}$ & $33.5^{\mathrm{b}} \pm 2.2$ & $35.6^{a} \pm 3.7$ & 0.617 & $50.9 \pm 4.5$ & $51.2 \pm 7.1$ & 0.143 \\
\hline & & & ratio $^{1}$ & $23.6 \pm 3.3$ & $28.5 \pm 3.5$ & 0.348 & $9.0 \pm 3.1$ & $10.0 \pm 3.4$ & 0.085 \\
\hline \multirow{4}{*}{ Diameter of small fibres $D s$} & \multirow{4}{*}{$\mu \mathrm{m}$} & M & $\bar{x}$ & $22.6 \pm 3.9$ & $24.0 \pm 3.2$ & 0.208 & $33.1 \pm 7.1$ & $35.2 \pm 6.4$ & 0.222 \\
\hline & & $\mathrm{F}$ & ratio $^{1}$ & $76.7 \pm 8.9$ & $76.6 \pm 8.3$ & 0.609 & $83.7 \pm 16.9$ & $81.5 \pm 13.2$ & 0.355 \\
\hline & & M & $\bar{x}$ & $19.6 \pm 4.3$ & $20.2 \pm 3.4$ & 0.208 & $28.7 \pm 5.5$ & $29.8 \pm 4.9$ & 0.222 \\
\hline & & $\mathrm{F}$ & ratio $^{1}$ & $76.4 \pm 7.1$ & $71.5 \pm 6.0$ & 0.609 & $91.0 \pm 14.2$ & $90.0 \pm 11.0$ & 0.355 \\
\hline \multirow{2}{*}{ Mean diameter of fibres $D \bar{x}$} & \multirow{2}{*}{$\mu \mathrm{m}$} & M & & $29.2^{\mathrm{b}} \pm 0.8$ & $32.3^{\mathrm{a}} \pm 0.8$ & \multirow{2}{*}{0.130} & $41.5^{\mathrm{b}} \pm 1.3$ & $44.0^{\mathrm{a}} \pm 1.2$ & \multirow{2}{*}{0.125} \\
\hline & & $\mathrm{F}$ & & $26.4^{\mathrm{b}} \pm 0.7$ & $29.5^{a} \pm 0.7$ & & $34.8^{\mathrm{b}} \pm 0.8$ & $38.3^{\mathrm{a}} \pm 0.9$ & \\
\hline \multirow{2}{*}{$\begin{array}{l}\text { Surface in cross section of fibres } \\
\text { S.s.t }\end{array}$} & \multirow{2}{*}{$\mu \mathrm{m}^{2}$} & M & & $729.3 \pm 344.6$ & $766.2 \pm 353.8$ & \multirow{2}{*}{0.245} & $859.5^{\mathrm{b}} \pm 356.4$ & $905.9^{a} \pm 358.1$ & \multirow{2}{*}{0.415} \\
\hline & & $\mathrm{F}$ & & $699.6 \pm 237.3$ & $733.6 \pm 238.3$ & & $866.8 \pm 264.2$ & $894.5 \pm 270.3$ & \\
\hline \multirow{2}{*}{ Fibres density D.f.m. } & \multirow{2}{*}{$\mathrm{fm} / \mathrm{mm}^{2}$} & M & & $751.1 \pm 166.2$ & $713.9 \pm 120.5$ & \multirow{2}{*}{0.590} & $595.0^{a} \pm 91.1$ & $467.4^{b} \pm 58.2$ & \multirow{2}{*}{0.346} \\
\hline & & $\mathrm{F}$ & & $844.7 \pm 212.1$ & $782.5 \pm 187.3$ & & $676.7^{\mathrm{a}} \pm 132.6$ & $543.4^{\mathrm{b}} \pm 88.4$ & \\
\hline \multirow{2}{*}{ Format index of fibres } & \multirow{2}{*}{$\%$} & M & & $73.3^{B} \pm 13.6$ & $78.4^{\mathrm{A}} \pm 12.4$ & \multirow{2}{*}{0.822} & $69.2 \pm 15.3$ & $71.3 \pm 13.3$ & \multirow{2}{*}{0.099} \\
\hline & & $\mathrm{F}$ & & $70.5^{B} \pm 14.8$ & $73.7^{\mathrm{A}} \pm 13.2$ & & $67.4 \pm 14.3$ & $69.1 \pm 14.9$ & \\
\hline
\end{tabular}

$\mathrm{a,b}$ - difference significant at $P \leq 0.05$ - the significance of differences was analysed only within one sex.

$\mathrm{M}$ - Males; F - Females.

${ }^{1}$ ratio - the ratio (\%) of large and small fibres in duck muscle. 
$(P<0.05)$. Thinner fibres were also demonstrated in pectoralis superficialis muscle of $\mathrm{P} 44$ IS ducks $(P$ $<0.05)$ and drakes $(P<0.01)$, whereas differences were not confirmed in their biceps femoris muscles (Tables 5 and 7). Interestingly, it seems also that leg muscles were always more diversified in terms of the analysed traits of muscle fibres, compared to the more homogenous fibres of pectoralis superficialis muscles, which may be seen in usually greater standard deviations. According to Torrella et al. (1996), in wild ducks this is linked with functions for which particular groups of muscles are responsible. The pectoralis superficialis muscles are mainly linked with aviation and wing motion that are strongly limited in domesticated fowl. In turn, the leg muscles undergo strenuous effort during walking, moving up, sitting down or perching on tree branches in the case of Muscovy ducks. In our study, the differences in diameters of biceps femoris fibres could be even more attributable to the high body weight of the birds (Tables 3 and 4).

The analysed parameters of muscle fibre sizes were usually higher in IS groups, and an opposite tendency was observed in fibre density $\left(\mathrm{fm} / \mathrm{mm}^{2}\right.$ ) (Tables 5 and 7 ). In each case this parameter was negatively correlated with muscle weight as well as diameter and cross-section of muscle fibres (Tables 6 and 8). The highest negative correlations (from -0.72 to -0.98 ) were determined between fibre density and fibre cross-section area, which seems obvious. It does not, however, depict the total number of fibres in the muscle. This information may be another (a similar correlation was demonstrated by Teuşan et al. (2011) who examined muscles of broiler chickens) confirmation that, regardless of the origin, sex or housing system of birds the number of fibres in muscles does not change or changes insignificantly, and that greater changes are observed in fibre size. No significant interactions were found between the housing system and sex of P44 ducks regarding muscle fibre traits. Both sexes were similarly responding to variable environmental conditions. Perhaps, it results from the lack of or very small sexual dimorphism in body weight and structure of muscles in the P44 ducks, similar to ducks originating from Anas platyrhynchos.

Table 8 Correlation coefficients $(r)$ between breast and leg muscle weight and pectoralis superficialis and biceps femoris muscle fibre size in female and male P44 ducks kept intensively (IS) and in the outdoor system (OS)

\begin{tabular}{|c|c|c|c|c|c|c|c|c|}
\hline \multirow{2}{*}{ Parameter } & & & \multicolumn{2}{|c|}{$\begin{array}{l}\text { Mean diameter of } \\
\quad \text { fibres } D \bar{X}\end{array}$} & \multicolumn{2}{|c|}{$\begin{array}{l}\text { Cross section of } \\
\text { fibres S.s.t. }\end{array}$} & \multicolumn{2}{|c|}{$\begin{array}{c}\text { Fibres density } / \mathrm{mm}^{2} \\
\text { D.f.m. }\end{array}$} \\
\hline & & & IS & os & IS & os & IS & os \\
\hline \multirow{6}{*}{$\begin{array}{l}\text { Pectoralis } \\
\text { superficialis }\end{array}$} & \multirow{2}{*}{ Weight $^{1}(\mathrm{~g})$} & M & 0.09 & 0.06 & 0.33 & 0.41 & -0.06 & -0.07 \\
\hline & & $\mathrm{F}$ & 0.12 & 0.08 & 0.32 & 0.38 & -0.05 & -0.11 \\
\hline & \multirow{2}{*}{$\begin{array}{l}\text { Mean diameter } \\
\text { of fibres } D \bar{X}\end{array}$} & $M$ & & & 0.59 & 0.61 & -0.50 & -0.52 \\
\hline & & $\mathrm{F}$ & & & 0.52 & 0.59 & -0.50 & -0.49 \\
\hline & \multirow{2}{*}{$\begin{array}{l}\text { Cross section of } \\
\text { fibres S.s.t. }\end{array}$} & M & & & & & -0.31 & -0.33 \\
\hline & & $\mathrm{F}$ & & & & & -0.29 & -0.35 \\
\hline \multirow{6}{*}{$\begin{array}{l}\text { Biceps } \\
\text { femoris }\end{array}$} & \multirow{2}{*}{ Weight (g) } & M & 0.07 & 0.14 & 0.41 & 0.43 & -0.12 & -0.09 \\
\hline & & $\mathrm{F}$ & 0.08 & 0.10 & 0.40 & 0.36 & -0.08 & -0.15 \\
\hline & \multirow{2}{*}{$\begin{array}{l}\text { Mean diameter } \\
\text { of fibres } D \bar{X}\end{array}$} & M & & & 0.55 & 0.56 & -0.77 & -0.79 \\
\hline & & $\mathrm{F}$ & & & 0.55 & 0.57 & -0.76 & -0.72 \\
\hline & \multirow{2}{*}{$\begin{array}{l}\text { Cross section of } \\
\text { fibres S.s.t. }\end{array}$} & M & & & & & -0.26 & -0.35 \\
\hline & & $\mathrm{F}$ & & & & & -0.29 & -0.32 \\
\hline
\end{tabular}

\footnotetext{
whole breast muscle; M - Males; F - Females.
} 


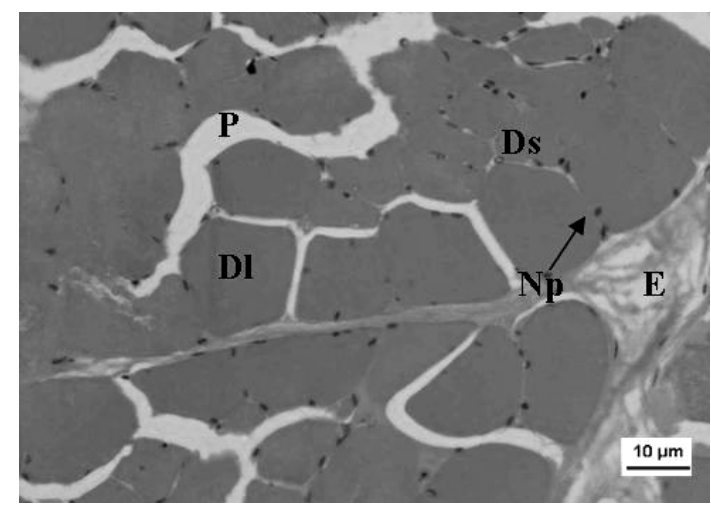

outdoor system

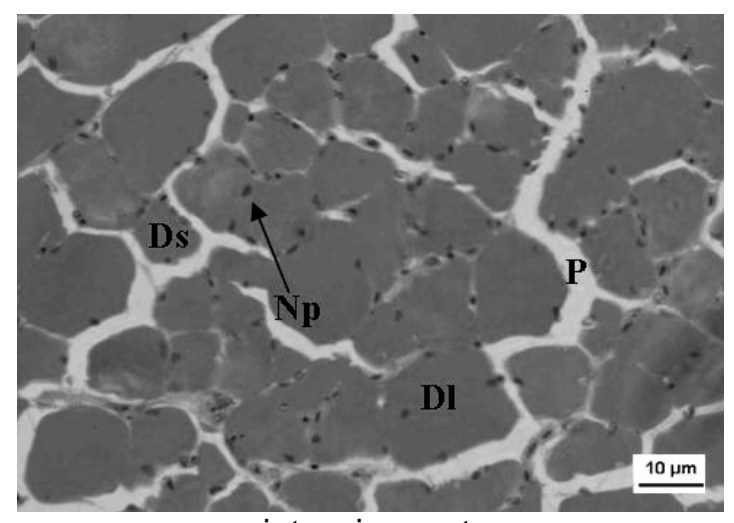

intensive system

Figure 2 Cross-section of pectoralis superficialis muscle of male MR71. DI - large diameter of fibre; Ds - small diameter of fibre; Np - peripheral nuclei; $\mathbf{E}$ - epimysium.

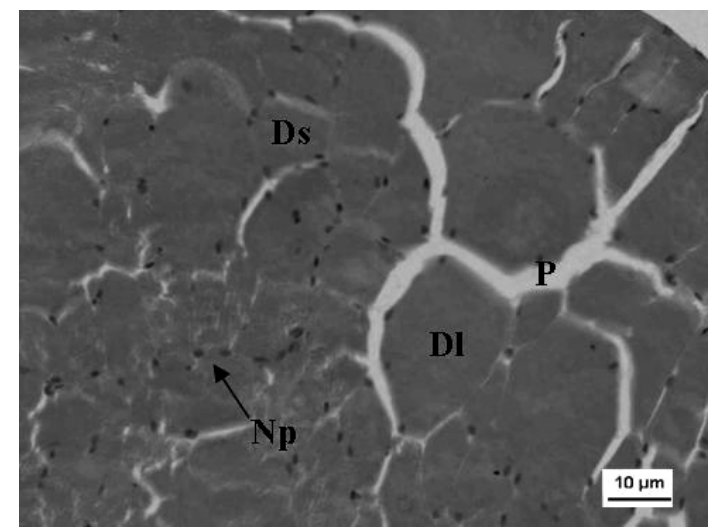

outdoor system

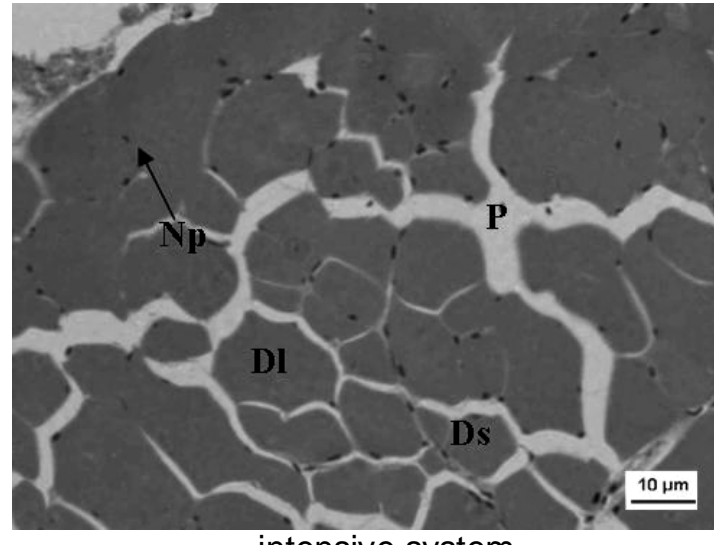

intensive system

Figure 3 Cross-section of pectoralis superficialis muscle of male P44. DI - large diameter of fibre; Ds - small diameter of fibre; $\mathbf{N p}$ - peripheral nuclei.

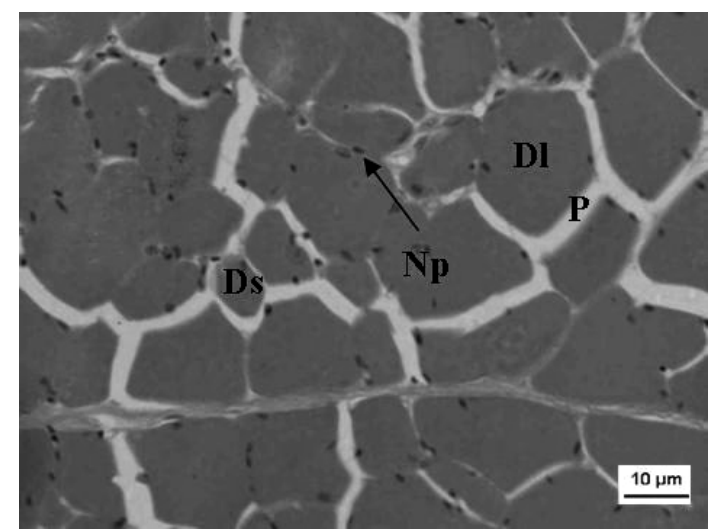

outdoor system

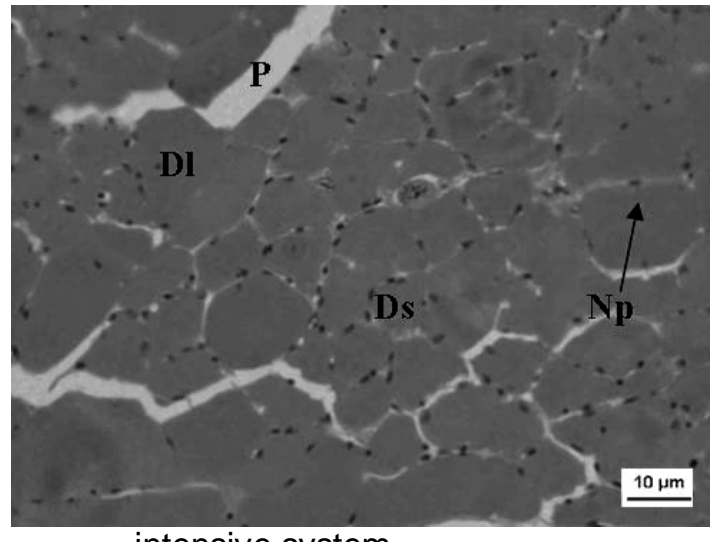

intensive system

Figure 4 Cross-section of biceps femoris muscle of male MR71. DI - large diameter of fibre; Ds small diameter of fibre; Np - peripheral nuclei. 


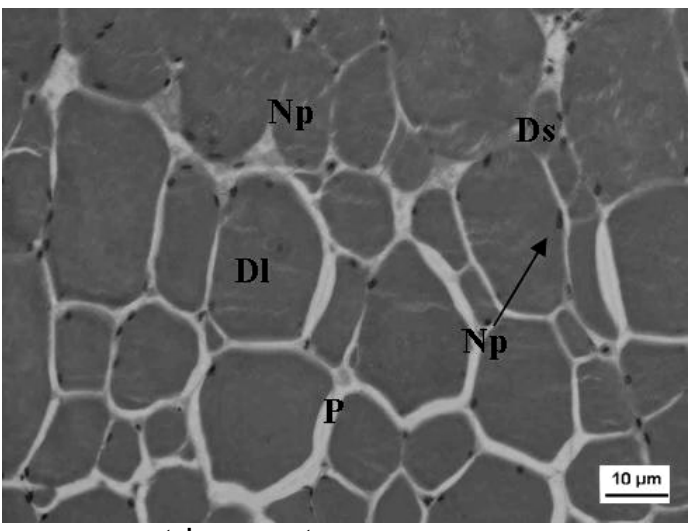

outdoor system

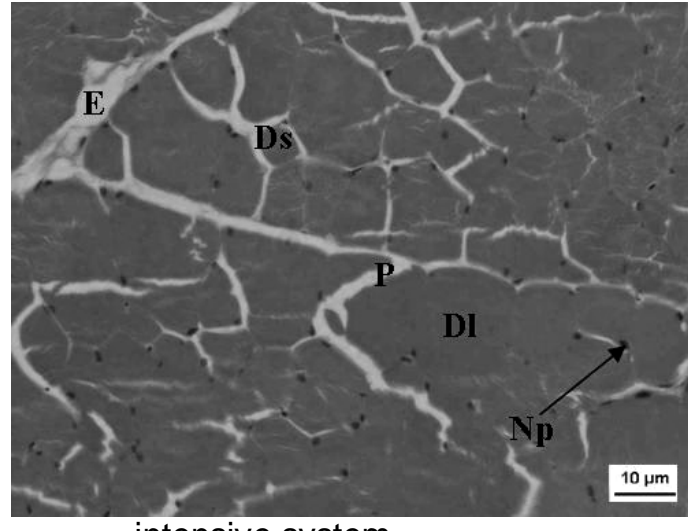

intensive system

Figure 5 Cross-section of biceps femoris muscle of male P44. DI - large diameter of fibre; Ds - small diameter of fibre; $\mathbf{N p}$ - peripheral nuclei; $\mathbf{E}$ - epimysium.

\section{Conclusion}

Results of this study demonstrate that even though the production of ducks in Europe is based almost entirely on the intensive system, periodically this species may be successfully reared in the outdoor system. It may be corroborated by the fact that, apart from a significantly lower slaughter yield of MR71 ducks, no negative effects of this production system were demonstrated in the study. Differences in the sizes of fibres in pectoralis superficialis muscle, and especially in biceps femoris demonstrate that the possibility of using free range by ducks facilitates the development of their skeletal muscles and stimulates their growth. Production of both Pekin and Muscovy ducks could therefore by carried out in central Europe in the outdoor system without significant economic losses.

\section{References}

AOAC, 2005. Official methods of analysis (16th ed.). Association of Official Analytical Chemists, Darlington, VA, USA.

Baéza, E., Salichon, M.R., Marche, G. \& Juin, H., 1998. Effect of sex on growth, technological and organoleptic characteristic of Muscovy duck breast muscle. Br. Poult. Sci. 39, 398-403.

Bochno, R., Murawska, D. \& Brzostowska, U., 2006. Age-related changes in the distribution of lean, fat with skin and bones in goose carcasses. Poult. Sci. 85, 1987-1991.

Cherry, P. \& Morris, T.R., 2008. Domestic Duck Productions. Science and Practice, Oxford, UK: CABI.

Erisir, Z., Poyraz, O. Onbasilar, E.E. Erdem, E. \& Kandemir, O., 2009. Effect of different housing systems on growth and welfare of Pekin Ducks. J. Anim. Vet. Adv. 8, 235-239.

Etuk, I.F., Abasiekong, S.F. Ojewola, G.S. \& Akomas, S.C., 2006. Carcass and organ characteristics of Muscovy ducks reared under three management system in South Eastern Nigeria. Int. J. Poult. Sci. 5, 534-537.

Faure, J.M., Val-Laillet, D. Guy, G. Bernadet, M.D. \& Guemene, D., 2003. Fear and stress reactions in two species of duck and their hybrid. Horm. Behav. 43, 568-572.

Gille, U., \& Salomon, F.V., 1998. The increase skeletal limbs of domestics and will ducks. Anat. Histol. Embryol. 24, 13-18 (in German).

Grimaud Fréres, 2012. http//www.grimaud.com. Accessed February 2012.

Horne, P.L.M. \& Achterbosch, T.J., 2008. Animal welfare in poultry production systems: impact of EU standards on world trade. Wrld's Poult. Sci. J. 64, 40-52.

Kisiel, T. \& Książkiewicz, J.M., 2004. Comparison of physical and quality traits of meat of two Polish conservative flocks of ducks. Arch. Tierz., Dummerstorf 47, 367-375.

Kokoszyński, D., Korytkowska, H. \& Korytkowski, B., 2010. Comparison of some meat traits of ducks from P44 and P55 flocks. Acta Sci. Pol., Zootech. 9, 21-28. (in Polish).

Lin, C.J. \& Hsu, C.Y., 2002. Effect of surgical caponization on growth performance, fiber diameter and some physical properties of muscle in Taiwan country chicken cockerels. Asian-Austral. J. Anim. 15, 401-405.

Mench, J.A., 1992. The welfare of poultry in modern production systems. Poult. Sci. Rev. 4, 107-128.

Michel, V. \& Huonnic, D., 2003. A comparison of welfare, health and production performance of laying hens reared cages or in aviaries. Br. Poult. Sci. 44, 775-776.

Mignon-Greasteau, S. \& Beaumont, C., 2000. Growth curves in birds. INRA Prod. Anim. 13, 337-348 (in France). 
Ostaszewska, T., Dąbrowski, K. Wegner, A. \& Krawiec, M., 2008. The effects of feeding on muscle growth dynamic and the proliferation of myogenic progenitor cells during Pike Perch development (Sander lucioperca). J. World Aquacult. Soc. 39, 184-195.

Raud, H. \& Faure, J.M., 1994. Welfare of ducks in intensive units. Revue Scientifique et Technique (International Office of Epizootics) 13, 119-129.

Sandu, G.H., 1995. Experimental methods in animal husbandry. Ed. Coral Sanivet, Bucureşti.

Sauveur, B., 1990. Origins and performance compared Muscovy and common Pekin duck race. Eds: Sauveur, B. \& De Carville, H., Le canard de Barbarie, INRA, Paris, France, 1990. pp. 3-11. (in French).

SPSS, 2010. Statistical Analysis Systems for Windows user's guide (5th ed.), by SPSS Ins. USA.

Swatland, H.J., 1980. Volumetric growth of muscle fibers in ducks. Grow. 44, 355-362.

Teuşan, V., Prelipcean, A. \& Prelipcean, P.P., 2011. Research on thickness and density of gamble twins muscles myocytes in commercial meat hybrid Cobb-500. Agro. Res. Mol. 3, 89-102.

Torrella, J.R., Fouces, V., Palomeque, J., \& Viscor, G., 1996. Capillarity and fiber types in locomotory muscles of wild mallard ducks (Anas platyrhynchos). J. Anat. 2, 211-222.

Wawro, K., Wilkiewicz-Wawro, E., Kleczek, K. \& Brzozowski, W., 2004. Slaughter value and meat quality of Muscovy ducks, Pekin ducks and their crossbreeds, and evaluation of the heterosis effect. Arch. Tierz., Dummerstorf 47, 287-299.

Wilkiewicz-Wawro, E., Bochno, R. \& Szeremeta, J., 1999. Effect of age and sex on carcass of ducks. Zeszyty Naukowe PTZ 45, 535-536. (in Polish, abstract).

Witkiewicz, K., Kontecka, H., Książkiewicz, J., Szwaczkowski, T. \& Perz, W., 2004. Carcass composition and breast muscle microstructure in selected vs non - selected ducks. Anim. Sci. Pap. Rep. 22, 65-73.

Zhang, J.E., Xu, R. Chen, X. \& Quan, G., 2009. Effects of duck activities and a weed community under a transplanted rice-duck farming system in southern China. Weed Biol. Manag. 9, 250-257. 